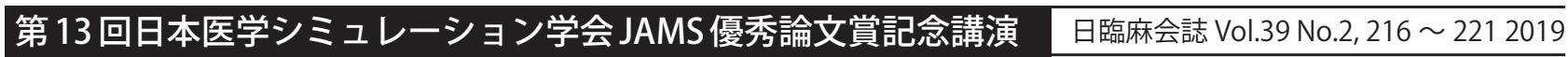

\title{
院内鎮静トレーニングの意義 一多職種連携推進におけるシミュレーション教育法の有用性一
}

\begin{tabular}{|c|c|}
\hline & 安宅一晃 ${ }^{* 2}$ \\
\hline 植木隆介*4 & 上農喜朗*5 \\
\hline
\end{tabular}

[要旨] 鎮静実践セミナーは, (1)米国麻酔科学会の非麻酔科医のための鎮静・鎮痛に関する診療ガ イドラインに基づいた講義，(2)タスクトレーナーを用いた急変初期対応と基本的気道管理，(3)薬剤 カードを用いたディスカッションに加え，(4)鎮静，鎮痛に関する術前評価，鎮静計画，臨床判断な どのノンテクニカルスキル獲得目的のシナリオトレーニングで構成される. われわれは, 鎮静実践 セミナーの効果を最大限にするため, 実際に鎮静を行う多職種の参加による院内シミュレーション 講習会の実施を推奨している. 鎮静実践セミナ一受講者による自施設での多職種連携講習会により, 医療従事者のノンテクニカルスキルの向上と鎮静医療安全の改善が期待できる.

キーワード : 鎮静, シミュレーション, 多職種連携, 教育工学

\section{はじめに}

米国麻酔科学会は,「非麻酔科医のための鎮静・ 鎮痛に関する診療ガイドライン」(Practice Guidelines for Sedation and Analgesia by Non-Anesthesiologists. An Updated Report by the American Society of Anesthesiologists Task Force on Sedation and Analgesia by Non-Anesthesiologists ${ }^{1), 2)}$, 以下ASA-SED)を発表した. 医学シミュレーショ ン学会鎮静委員会は, 各診療科の医師, 歯科医師, 看護師などを含めた医療従事者を対象としたセデー ショントレーニングコース (鎮静実践セミナー)を開 発した。学習目標を明確化し ${ }^{3)}$, コース開催を重ね る中で, 教育工学の観点からコース設計改善を継続 的に行っている4).

本稿では，実臨床での鎮静医療安全向上を目指し

${ }^{* 1}$ 大阪医科大学麻酔科学教室

*2奈良県総合医療センター集中治療部

*3 国保日高総合病院麻酔科

*4 兵庫医科大学麻酔科学講座

*5 紀南病院麻酔科
た，多職種参加による院内型講習会の重要性を述べ る.

\section{I＼cjkstart公募型鎮静実践セミナーの限界点}

鎮静実践セミナーの内容は，(1) ASA-SED を核と した知識習得のための講義，(2)鎮静薬と鎮痛薬を記 載したカードを用いた討議形式のカードシミュレー ション，(3)気道管理訓練用マネキンを用いた基本的 気道管理手技ハンズオントレーニング，(4)鎮静に関 する知識・技術・判断能力を統合するための Problem-based learning discussion(PBLD) や人型シミ ュレーターなどのシミュレーション環境を用いたシ ナリオトレーニングであった。講習会を継続開催し ながら, 受講生の意識変化および, 意識改善を調査 するなどの試みを行った ${ }^{5)}$. 6).さらに，デブリーフ イングによる受講生の知識的コンピテンシーの変化 


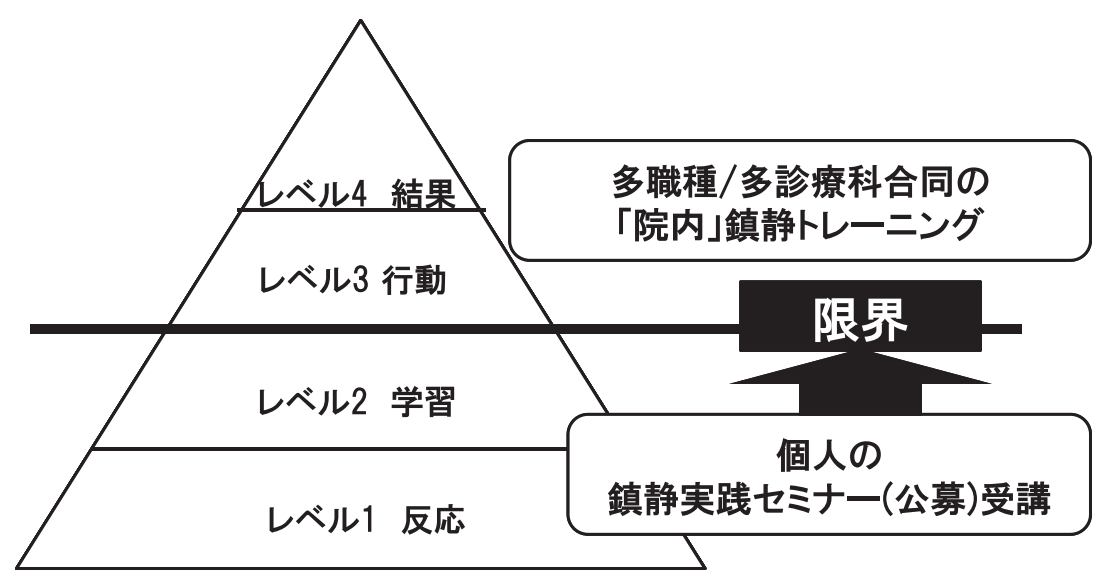

図1 カークパトリックモデルと鎮静実践セミナーの学習効果

を調査した ${ }^{7)}$.

しかし，その他の多くのシミュレーション講習会 と同様に, 初期のコース内容では, 受講生の意識変 化もしくはアクティブラーニング活性化にとどま り, 教育効果を表すカークパトリックモデルのレベ ル1もしくはレベル2は超えられないと考え，コー ス改良を目指した(図1).

\section{II 教育工学による鎮静実践セミナーの改良と目標}

海外のシミュレーションセンターや教育工学の文 献収集および8)，鎮静委員会における討論により， 鎮静実践セミナーの改善点として,

(1)多診療科・多職種の受講生の学習ニーズ把握

(2)鎮静深度の連続性に対する評価法

(3)各診療科・各職種の鎮静医療安全改善のための 方法明確化

の必要性が挙げられ, コース改良を行うこととした。

表1のように, 従来のコース内容に, 学習ニーズ の把握や疑問点の明確化を目的とした受講前アンケ ート実施，鎮静梁度評価のためのトレーニング，お よびコース総括時の鎮静関連の医療安全改善に関す る受講後アンケートとディスカッションを加えた. さらに, 受講前アンケートを行うことで, 学習者で ある受講生とインストラクター双方が学習ニーズと 目標をより明確にすることを試みた。学習ニーズを
意識しながら，気道管理ハンズオン，カードシミュ レーション，模擬患者とモニターを併用した鎮静深 度評価を行った ${ }^{4)}$ 。そして，これらの統合として， 状況分析と臨床的判断, 医療者間の情報共有などの ノンテクニカルスキルを含めたシナリオトレーニン グを位置づけた。そして，総括として，医療者個人 およびシステム面での鎮静の医療安全改善行動につ いて，ディスカッションを行った" ${ }^{4)}$.

また, コース進行時に常に鎮静計画, 実行, 変更, 鎮静後評価のプロセスを意識づけ(表2)，コース全 体を通して，ガイドラインに基づく薬剤投与の原則 (表3)も提示した.

鎮静医療安全のためには，1人の医療従事者の意 識改善だけでは不十分である。すなわち，鎮静に関 連するすべてのメディカルスタッフの意識改善と多 職種連携が必要である ${ }^{5)}$. 6) 総括時に, 自施設で講 習会内容を共有し行動改善に結び付けること, もし くは院内のメディカルスタッフとともにシミュレー ション講習会を行うことを推奨した。これにより, 教育効果を示すカークパトリックモデルのレベル 3 (行動)からレベル4(結果)の達成を目指した.

改編した鎮静実践セミナーの到達目標は，1. 鎮静 に関するガイドラインの理解と実践，2. 過鎮静時の 気道・呼吸系を中心とした急変対応，3. 多職種連携 による鎮静医療安全システムの改善, である。 
表 1 現在の鎮静実践セミナーの構成

\begin{tabular}{|c|c|}
\hline 学習項目 & 学習目標 \\
\hline 受講前アンケート & 学習ニーズと鎮静管理に関する疑問点整理とインストラクターとの共有 \\
\hline 講義 & $\begin{array}{l}\text { 米国麻酔科学会「非麻酔科医のための鎮静・鎮痛ガイドライン」の解説 } \\
\text { 医療システム改善の重要性を強調 (院内コンセ室基準) }\end{array}$ \\
\hline カードを用いたシミュレーション & $\begin{array}{l}\text { 鎮静薬と鎮痛薬分類, 拮抗薬使用方法, 相互作用の把握, 疑問点の解消と } \\
\text { ディスカッション }\end{array}$ \\
\hline 緊急時気道管理ハンズオン & $\begin{array}{l}\text { 呼吸状態の評価を意識づけ(呼吸パターン, 回数, } \mathrm{SpO}_{2} \text { など), 酸素投与法, } \\
\text { タスクトレーナーを用いた基本的気道管理(バッグバルブマスク, 経ロ経 } \\
\text { 鼻エアウェイ, 声門上器具)の習得 }\end{array}$ \\
\hline 鎮静深度評価訓練 & 模擬患者とバイタルサインモニター画面を併用して鎮静深度の評価を行う \\
\hline $\begin{array}{l}\text { Problem-based learning discussion } \\
\text { もしくは人型シミュレーターを用いた } \\
\text { シナリオトレーニング }\end{array}$ & $\begin{array}{l}\text { 臨床での実践対応に関してProblem-based learning discussion もしくは人 } \\
\text { 型シミュレーターを用いてシナリオトレーニング }\end{array}$ \\
\hline $\begin{array}{l}\text { 受講後アンケートと } \\
\text { ディスカッシン }\end{array}$ & $\begin{array}{l}\text { 鎮静の医療安全改善のために個人の改善点とシステムの改善点を検討し, } \\
\text { 全体で討議を行う }\end{array}$ \\
\hline
\end{tabular}

〔文献4)より引用・一部改変〕

表2 鎮静実践セミナーで強調する鎮静のプロセス

1. 患者術前評価と鎮静計画 (モニタリング等)

2. 鎮静実行

3. 患者再評価と鎮静変更

4. 鎮静終了後の患者評価(退室基準等)

\section{IIII鎮静の多職種連携推進における シミュレーション教育の意義}

現在の各領域において，鎮静は日常医療行為とし て行われている。しかし，各施設や各診療科によっ て, 必要鎮静深度や鎮静方法, 危機管理に対する認 識，そして終了後の退室基準も多様である。鎮静実 践セミナーは，ASA-SED に基づいた鎮静の医療安 全管理を学ぶことで, 各施設や診療分野の鎮静医療 における改善を目標としている。

鎮静実践セミナーでは, 受講後アンケートを用い て受講生の鎮静医療安全に対する，個人および組織 での行動改善の意識付けを行っている。 また, 総括 において, 個人の注意点とシステム改善項目を討論 し共有することは，自施設での円滑な医療安全改善
表 3 鎮静実践セミナーにおける薬剤投与の注意点

1. 呼吸・循環抑制のない鎮静薬は存在しない

2. 鎮静薬と鎮痛薬は相乗効果がある

3. 鎮静深度は患者ごとに評価する(反応性は異なる)

4. 拮抗薬は鎮静薬より作用時間が短い 再効果発現に注意する

5. 薬剂は「最大効果発現時間」と「半減期」を理解して 使用する

行動に結び付くと考えている.

しかし，自施設での医療安全改善には，鎮静実践 セミナーを受けた個人だけでは不十分であり，鎮静 に関連する全体の意識変化，すなわち多職種連携に よるコンセンサス形成が重要である.

鎮静の多職種連携推進の第一歩として，鎮静安全 管理の意義を，関連するすべてのメディカルスタッ フが理解することが必要である。そして，多職種連 携による鎮静医療安全改善コンセンサス作成のため に，off-the-job，すなわち臨床業務の緊張感がない 場所で，多職種・多診療科で集合し各術式や患者状 態に対応する鎮静トレーニングを行う必要がある。 ここで重要なことは，科長や師長などの責任者だけ 


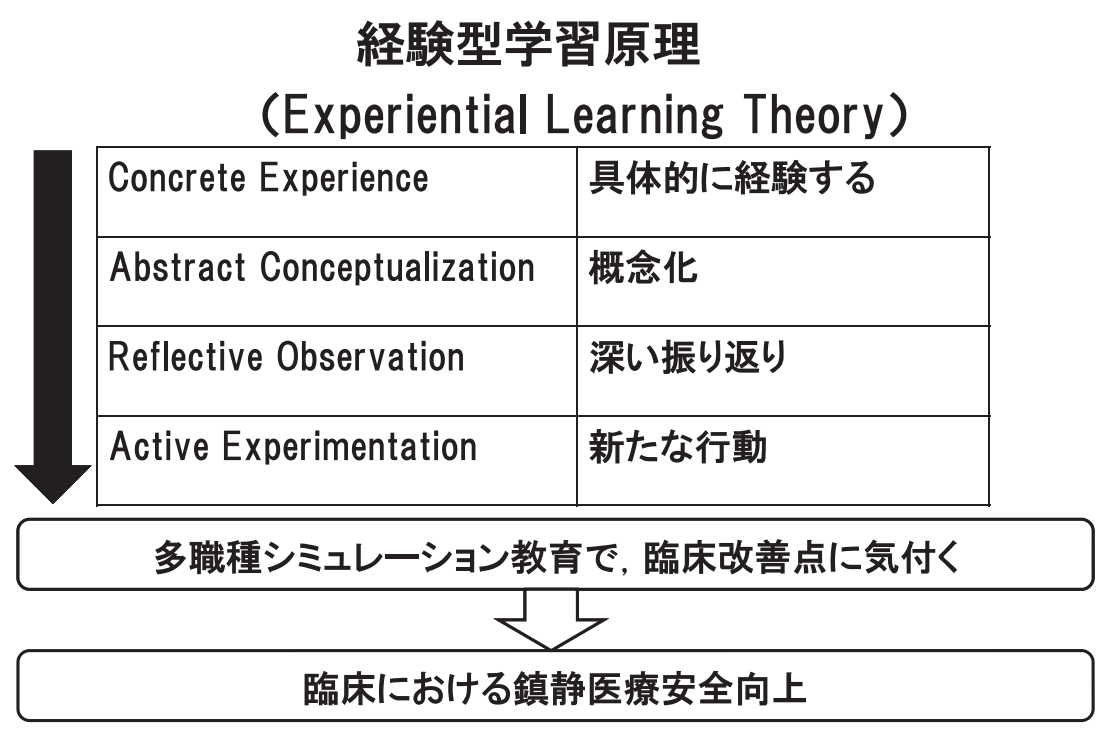

図2 経験型学習理論とシミュレーション教育の意義

〔文献 8)より引用・一部改変〕

でなく, 実務的に手術室内に勤務する医師, 看護師, 臨床工学技士が参加し，自由に意見発信できること である。言い換えると，鎮静実践セミナーを受けた 医療者により各施設で「院内向け鎮静実践セミナー」 を行うことが推奨される。現場で働く多職種でシミ ユレーションという経験型学習を行い, そこで得た 共通の気付きを臨床現場へ還元することは容易であ る $(\text { 図2 })^{8)}$.すなわち，鎮静実践セミナー受講者は 各施設での多職種連携講習会もしくは検討会の核と なる「鎮静プロバイダー」の役割が期待される。

\section{IV 鎮静の院内教育における ノンテクニカルスキル涵養の方法}

では，院内向け鎮静実践セミナーを行うにはどの ような方略が必要だううか? 鎮静実践セミナーで 必要なスキルは, 緊急時気道確保のテクニカルスキ ルを除くと，ノンテクニカルスキル主体である。 ンテクニカルスキルは, 状況判断やコミュニケーシ ヨン, 協調性などのいわゆるテクニカルスキルでな いもの全般を指す。

人型シミュレーターを用いて行うシナリオ型シミ
ュレーションは，欧米では災害，救急医学領域での 研究から, 多職種連携におけるノンテクニカルスキ 儿獲得に有効という報告が多い ${ }^{9)}$. これらのシナリ オ型シミュレーションが有効な理由としては，シナ リオ終了後のデブリーフィングの意義が挙げられて いる ${ }^{10)}$. 自身のスキルだけでなく，チームで構築す る連携スキルを評価し合うことで，ノンテクニカル スキルを効果的に向上できる。 シナリオ型シミュレ ーションにより，チーム全体の連携スキルの向上だ けでなく, 医療安全面での課題発見と改善目的にも 有効である.

多職種参加型のシミュレーション講習会の例とし て, 大阪医科大学附属病院は教育病院群(第一東和 会病院, 市立ひらかた病院, 北摂総合病院, 高㭇赤 十字病院，松下記念病院）と合同で，多職種連携訓 練において上記のようなシナリオベースの人型シミ ユレーターを用いたシミュレーショントレーニング だけでなく,PBLDも多職種連携のための研修会に 使用している ${ }^{11)}$. 自病院や他病院の重篤な鎮静事故 事例や危機的事例をPBLD の形式で提示し，シナリ オ進行時にそれぞれの職種からの判断を質問する. 
これにより, 自分の職種的観点だけでなく他職種の 観点を獲得することができ, 円滑なコミュニケーシ ヨンや連携能力向上などのノンテクニカルスキル向 上に有効である.

多職種連携教育において, シナリオトレーニング の際に人型シミュレーターとPBLDの選択に難渋す ることも多い。それぞれの病院における学習目標, 参加人数, 経験レベルに合わせて, 教育工学的知見 により適切な教育方法を使い分けることが好ましい. そして，このように鎮静に関連する医療者全員で のシミュレーションを用いた経験型学習は, 鎮静医 療安全向上等に寄与し, カークパトリックモデルの レベル 3, レベル 4 の医療安全改善行動や結果が達 成できる(図1).

\section{おわりに}

現在，医療の質を評価する Joint Commission International(JCI) が注目されている.JCIの14分野 1,220項目にわたる医療システム審査項目に「鎮静 の質の向上」が含まれている。これは, 適切な鎮静 管理方法, 副作用対応への危機意識を重視し, 各分 野での鎮静に対する医療安全意識の活性化を期待し ていることの裏付けである。鎮静実践セミナー受講 者が「鎮静プロバイダー」として, 各施設で鎮静卜 レーニングを行うことで, 鎮静医療安全体制が向上 することを祈念する.

\section{謝辞}

鎮静実践セミナーのこれまでの開催に協力いただ いたインストラクターおよび受講者の皆様に深甚の 謝意を表する。

\section{参考文献}

1) Practice Guidelines for Sedation and Analgesia by
Non-Anesthesiologists. An Updated Report by the American Society of Anesthesiologists Task Force on Sedation and Analgesia by Non-Anesthesiologists. Anesthesiology $96:$ 1004-1017, 2002

2）駒澤伸泰, 中川雅史, 安宅一晃ほか：非麻酔科医によ る鎮静/鎮痛に関する診療ガイドライン: 非麻酔科医に よる鎮静/鎮痛に関する米国麻酔科学会作業部会による 改訂情報．医療の質・安全学会誌 $7: 162-181,2012$

3）駒澤伸泰, 安宅一晃, 上嶋浩順ほか: 非麻酔科医を対 象としたSED 実践セミナー(セデーショントレーニング コース)の展開一学習目標の作成を含めて一, 麻酔 63 : 582-585, 2014

4）駒澤伸泰, 羽場政法, 植木隆介ほか：教育工学に基づ いた鎮静トレーニングコース (SED 実践セミナー)の改 良一模擬患者を用いた評価型シナリオの導入一, 麻醉 $66: 996-1000,2017$

5) Komasawa N, Fujiwara S, Atagi K, et al. : Effects of a simulation-based sedation training course on non-anesthesiologists' attitudes toward sedation and analgesia. J Anesth $28: 785-789,2014$

6）駒澤伸泰，安宅一晃，讃岐拓郎ほか：麻酔科が提供す る鎮静管理の医療安全一SED 実践セミナーの臨床応用 一. 日本臨床麻酔学会誌 $36: 334-338,2016$

7) Komasawa N, Sanuki T, Fujiwara S, et al. : Significance of debriefing methods in simulation-based sedation training courses for medical safety improvement in Japan. Springerplus $3: 637,2014$

8）駒澤伸泰, 南敏明：麻醉科学と周術期医学領域におけ る教育工学の応用. 臨床麻酔 $41: 693-700,2017$

9) Komasawa N, Berg BW : Interprofessional simulation training for perioperative management team development and patient safety. J Perioper Pract $26: 250-253$, 2016

10) Komasawa $\mathrm{N}$, Berg BW, Minami $\mathrm{T}$ : Effective Interprofessional Perioperative Training Requires not Only Multi-Professional and Multi-Department, but also Multi-Hospital Participation. J Surg Educ 74 : 545-546, 2017

11) Komasawa N, Berg BW, Minami $T$ : Problem-based learning discussion on advanced life support training for perioperative interprofessional education. Am J Emerg Med 35 : 1017, 2017 


\title{
Need for In-hospital Simulation-based Sedation Training Course : Significance of Interprofessional Training for Medical Safety Improvement
}

\author{
Nobuyasu KOMASAWA ${ }^{* 1}$, Kazuaki ATAGI*2, Masanori HABA*3, \\ Ryusuke UEKI*4, Yoshiroh KAMINOH* ${ }^{* 5}$, Toshiaki MINAMI*1 \\ ${ }^{* 1}$ Department of Anesthesiology, Osaka Medical College \\ ${ }^{* 2}$ Department of Intensive Care Unit, Nara Prefectural General Medical Center \\ ${ }^{* 3}$ Division of Anesthesiology, Hidaka General Hospital \\ ${ }^{* 4}$ Department of Anesthesiology, Hyogo College of Medicine \\ ${ }^{* 5}$ Department of Anesthesiology, Kinan Hospital
}

Here we report on the application of educational technology to improve the simulation-based sedation training course (SEDTC) hosted by the Japanese Association for Medical Simulation and discuss the significance of interprofessional training for practical medical safety improvement. SEDTC consists of lecture, basic airway management, sedative and analgesic discussion, patient sedation depth evaluation, and scenario-based training. However, merely participating in the SEDTC can achieve level 1 (reaction) or level 2(learning) in the Kirkpatrick model. Medical safety improvement of level 3 (transfer) or level 4(result) in the Kirkpatrick model can be achieved when all members involved in sedation undergo experiential learning and achieve consensus. To achieve level 3 or 4 in the Kirkpatrick model, we added a questionnaire and discussion to determine which points require improvement, both for particular individuals and for the medical safety system.

Key Words : Sedation, Simulation training, Interprofessional collaboration, Educational technology

The Journal of Japan Society for Clinical Anesthesia Vol.39 No.2, 2019 